\title{
PENGARUH PAJAK, RETRIBUSI, DBH, BELANJA MODAL, DAN PERTUMBUHAN EKONOMI TERHADAP KEMANDIRIAN DAERAH
}

\author{
Maya Novitasari ${ }^{1}$, Lita Novitasari ${ }^{2)}$ \\ Fakultas Ekonomi dan Bisnis Universitas PGRI Madiun \\ maianov87.mngmail.com ${ }^{1)}$, litanov4@ gmail.com²)
}

\begin{abstract}
This research is to empirically prove the influence of Local Taxes, Regional Levies, Revenue Sharing Funds, Capital Expenditures, Economic Growth on Regional Financial Independence in Regencies / Cities in East Java Province 2014-2017 period. The analytical method used in this study is a quantitative method with multiple regression tests, by conducting the Classical Assumption test first before reaching the best study model. The total population of this study is 38 districts / cities consisting of 29 districts and 9 cities in East Java Province. The sampling technique is to use a census. The results of this study are: Regional Taxes, Regional Levies, and Capital Expenditures affect the Regional Financial Independence, Revenue Sharing and Economic Growth does not affect the Regional Financial Independence. Simultaneously the Regional Tax, Regional Retribution, Revenue Sharing Funds, Capital Expenditures, and Economic Growth influence the Regional Financial Independence.
\end{abstract}

Keywords: Regional Taxes, Regional Retribution, Revenue Sharing Funds, Capital Expenditures and Economic Growth, Regional Financial Independence.

\section{Abstrak}

Penelitian ini adalah untuk membuktikan secara empiris pengaruh Pajak Daerah, Retribusi Daerah, DBH, Belanja Modal, dan Pertumbuhan Ekonomi terhadap Kemandirian Keuangan Daerah. Metode penelitian analisis yang digunakan dalam penelitian ini adalah metode kuantitatif dengan uji regresi linear berganda. Populasai dan sampel dalam penelitian ini adalah 38 kabupaten/kota terdiri dari 29 kabupaten dan 9 kota di provinsi Jawa Timur tahun 2014-2017. Teknik pengambilan sampel yaitu dengan menggunakan sampel jenuh. Hasil dari penelitian ini adalah pajak daerah, retribusi daerah, dan belanja modal berpengaruh terhadap kemandirian keuangan daerah. Sedangkan DBH dan pertumbuhan ekonomi tidak berpengaruh terhadap kemandirian keuangan daerah. Secara silmutan pajak daerah, retribusi daerah, DBH, belanja modal, dan pertumbuhan ekonomi berpengaruh terhadap kemandirian keuangan daerah.

Kata Kunci: Pajak, Retribusi, DBH, Belanja, Kemandirian.

\section{PENDAHULUAN}

Masyarakat Bojonegoro Jawa Timur, telah memiliki pendapatan Rp. 4,6 triliun di rancangan APBD tahun 2019. APBD Bojonegoro ini dapat dikatakan APBD yang terbesar diantara APBD yang didapat oleh kabupaten/kota di Jawa Timur lainnya. Namun, besarnya pendapatan yang diterima oleh Bojonegoro ini tidak dapat menjadikan Bojonegoro sebagai daerah yang mandiri. Hal ini dibuktikan dengan masih tingginya tingkat ketergantungan kabupaten Bojonegoro terhadap dana perimbangan yang dipeoleh dari bantuan pemerintah pusat. Hal itulah yang masih menjadi sorotan Gubernur Jawa Timur dalam evaluasi RAPBD yang diajukan Buoati Bojonegoro dan DPRD (Redaksi Detak Pos-Opini).

Pemerintah memberlakukan kebijakannya mengenai otonomi daerah. Otonomi daerah ditempatkan secara utuh di daerah kabupaten dan kota, dengan harapan pemerintah daerah mampu menyelesaikan permaslahan daerah secara mandiri dan dapat membuat daerahnya menjadi lebih baik. Suatu daerah yang dapat membiayai sendiri kegiatan pemerintahannya tanpa harus mengandalakan bantuan dari pemerintah pusat dapat dikatakan sebagai 
daerah yang mandiri. Pendapatan asli daerah berperan besar dalam kemandirian daerah, tetapi sering kali aspek belanja pada umumnya masih didasarkan pada dana perimbangan sehingga kemampuan dalam meningkatkan PAD kurang diperhatikan. Akibatnya suatu pemerindah daerah banyak yang masih mengandalkan dana transfer dari pemerintah pusat yang diharapkan akan semakin besar disetiap tahunnya. Apabila hal ini terus terjadi maka kemandirian tidak akan terwujud (Sanga, dkk. 2018:3).

Kemandirian daerah dapat diwujudkan oleh berbagai hal, belanja modal misalnya. Pembangunan dan perbaikan daerah diberbagai sektor merupakan wujud dari belanja modal (Nurdiwaty, 2017:45). Perbaikan pada tingkat operasional suatu daerah akan memperbaiki perekonomian daerah tersebut. Pertumbuhan ekonomi merupakan gambaran yang nyata dalam mengembangkan perekonomian daerah. Laju pertumbuhan ekonomi meningkat maka kemandirian keuangan juga akan meningkat (Gaghana, dkk. 2018:2).

Penelitan yang sudah dilakukan oleh Nggilu, dkk. (2016), dengan judul pengaruh pajak daerah dan retribusi daerah terhadap kemandirian daerah pada pemerintah kabupaten/kota di provinsi Gorontalo. Penelitian tersebut memperoleh hasil pajak daerah dan retribusi daerah berpengaruh terhadap kemandirian keuangan daerah. Berbeda dengan penelitian yang dilakukan oleh Novalistia, (2016), dengan judul pengaruh pajak daerah, retribusi daerah, lain-lain pendapatan yang sah, dana bagi hasil pajak, terhadap kemandirian keuangan daerah pada pemerintahan kabupaten/kota di

\section{KAJIAN TEORI DAN Stakeholder Theory}

provinsi Jawa Tengah. Hasilnya adalah pajak berpengaruh postif terhadap kemandirian keuangan daerah, sedangkan retribusi tidak berpengaruh terhadap kemandirian keuangan daerah. Penelitian ini adalah replikasi dari penelitian yang dilakukan oleh Novalistia (2016). Perbedaan terletak pada variabel independennya yaitu dengan menghilangkan variabel lain-lain pendapatan yang sah kemudian menambahkan variabel belanja modal dan pertumbuhan ekonomi. Perbedaan lain terletak pada tempat dan periode waktu penelitian. Berdasar pada latar belakang diatas penelitian ini memiliki tujuan sebagai berikut:

1) Untuk membuktikan secara empiris pengaruh pajak daerah terhadap tingkat kemandirian keuangan daerah.

2) Untuk membuktikan secara empiris pengaruh retribusi daerah terhadap tingkat kemandirian keuangan daerah.

3) Untuk membuktikan secara empiris pengaruh dana bagi hasil terhadap tingkat kemandirian keuangan daerah.

4) Untuk membuktikan secara empiris pengaruh belanja modal terhadap tingkat kemandirian keuangan daerah.

5) Untuk membuktikan secara empiris pengaruh pertumbuhan ekonomi terhadap tingkat kemandirian keuangan daerah.

6) Untuk membuktikan secara empiris pengaruh pajak daerah, retribusi daerah, dana bagi hasil, belanja modal, dan pertumbuhan secara bersama-sama terhadap tingkat kemandirian keuangan daerah. 
Stakeholder theory adalah masyarakat atau sekumpulan orang baik secara bersama-sama maupun mandiri yang memiliki kepentingan dan hubungan terhadap suatu organisasi (Putro, 2013). Jadi maksud dari teori ini pemerintah sebagi pemegang kekuasaan dalam suatu pemrintahan harus mengutamakan kepentingan rakyat selaku stakeholder. Rakyat dan pemerintah harus ada hubungan timbal balik untuk terciptanya keseimbangan pemerintah.

\section{Akuntansi Keuangan Daerah}

Akuntasi keuangan

daerah merupakan proses identifikasi, pengukran, pencatatan, dan pelaporan atas transaksi ekonomi pemerintah daerah yang diperlukan sebagai bahan informasi untuk pegambilan keputusan (Halim dan Kusufi. 2014:43). Keuangan daearh harus dikelola dengan tertib, transparan, efektif dan efisien serta sesuai dengan perundangaundangan yang berlaku (Erawati dan Susan, 2015:3).

\section{Penganggaran Sektor Publik}

Anggaran merupakan " pernyataan mengenai estimasi kinerja yang akan dicapai oleh suatu organisasi dalam suatu periode tertentu yang dinyatakan dalam ukuran moneter" (Mahsun, 2013:145). Anggaran dalam akuntansi sektor publik merupakan instrument akuntabilitas atas pengelolaan dana publik dan pelaksanaan program-program yang dibiayai dengan uang public. Pengangagran dalam akuntansi sektor publik adalah aktivitas yang penting karena berkaitan dengan proses penentuan alokasi dana untuk aktivitas dan program pemerintahan.

\section{Anggaran Pendapatan dan Belanja Daerah (APBD)}

Anggaran daerah yang menggambarkan perkiraan pengeluaran setinggi-tingginya yang digunakan untuk membiayai kegiatan dan proyek pemerintahan salam periode tertentu disebut dengan APBD. Dalam APBD memuat semua penghasilan untuk menutup pengeluaran yang digunakan untuk membiayai proyek tersebut (Halim dan Kusufi, 2014:21).

\section{Pendapatan Asli Daerah}

Dana yang bersumber dari pendapatan yang diterima oleh suatu daerah yang berasal dari peneimaan hasil ekonomi asli daerah itu sendiri disebut dengan pendapatan asli daerah. PAD sebagai sumber penerimaan daerah harus ditingkatkan, karena dengan meningkatnya PAD kemandirian daerah dapat tercipta.

\section{Pajak Daerah}

Pajak adalah biaya yang dibebankan atau dikenakan oleh pemerintah pada suatu produk, pendapatan, atau kegiatan yang terjadi dalam batas teritorialnya. Pendapatan asli daerah yang bersumber dari pajak disebut dengan pajak daerah. Alasan utama perpajakan adalah untuk membiayai pemerintahan dan pembangunan suatu wilayah atau negara. Pajak dianggap sebagai kontribusi utama suatu pendapatan diberbagai negara (Nwanne, 2015:81).

\section{Retribusi Daerah}

Hasil pungutan daerah yang berasal dari pembayaran atas jasa atau pemberian izin tertentu yang khusus diberikan oleh pemerintah daerah kepada orang pribadi atau badan untuk kepentigan tertentu disebu dengan retribusi daerah (Halim dan Kusufi, 2014:102). Retribusi merupakan bagian dari PAD, sehingga retribusi juga dianggap sebagai salah satu penopang 
untuk terciptanya suatu kemandirian. Suatu daerah yang mampu menghasilkan retribusi yang tinggi akan dapat membantu menciptakan kemandirian keuangan pada masing-masing daerah.

\section{DBH (Dana Bagi Hasil)}

Dana bagi hasil termasuk dalam kategori dana perimbangan. Dana perimbangan berdasarkan Pemendagri Nomor 13 tahun 2006, dana perimbangan merupakan dana yang bersumber daeri APBN yang alokasinya kepada daerah digunakan untuk membiayai suatu kegiatan pemerintahannya dalam rangka desentralisasi fiskal yang tujuannya untuk mendapatkan keseimbangan keuangan antara pemerintah pusat dan pemerintah daerah. Terdapat dua kategori dana bagi hasil yaitu dana bagi hasil pajak dan dana bagi hasil bukan pajak.

\section{Belanja Modal}

Anggaran yang dikeluarkan untuk memperoleh aset tetap dan aset lainnya yang dapat memberikan manfaat lebih dari satu periode akuntansi dinamakan dengan belanja modal (Siregar, 2014:167). Dana yang digunakan untuk belanja modal dapat berasal dari pendapatan asli daerah maupun bantuan atau transfer daeri pemerintah pusat. Belanja modal bertujuan untuk pembangunan dan perbaikan diberbagai sektor,. Apabila suatu daerah tingkat operasionalnya baik dan sarana prasarananya baik maka dapat menunjang kelancaran usaha sehingga kemandirian dapat tercapai.

\section{Pertumbuhan Ekonomi}

Perkembangan kegiatan ekonomi masyarakat yang menyebabkan barang dan jasa yang diprodksikan semakin meningkat disebut dengan pertumbuhan ekonomi.Ukuran yang sering diginakan untuk menghitung pertumbuhan ekonomi adalah Produk Domestik Bruto (PDB). Pertumbuhan ekonomi daerah dapat juga diukur dengan menggunakan Produk Regional Domestik Bruto (PDRB). Tingkat pertumbuhan ekonomi dapat dihitung dengan cara membandingkan PDRB tahun tertentu dengna PDRB tahun sebelumnya berdasar atas haga konstan.

\section{Kemandirian Keuangan Daerah}

Suatu daerah dapat dikatakan mandiri apabila daerah tersebut mampu membiayai kegiatan pemerintahan dan pembangunannya secara mandiri tanpa mengandalkan dana dari pemerintah pusat. Kemandirian daerah merupakan tujuan dari otonomi daerah. Rasio kemandirian daerah dapat dilihat dari pendapatan asli daerah dibandingkan dengan total pendapatan daerah. semakin tinggi rasio kemandirian, maka semakin rendah tingkat ketergantungan pemerintah daerah terhadap pemerintah pusat. Sebaliknya, semakin rendah rasio kemandirian daerah maka semakin tinggi tingkat ketergantungan daerah terhadap bantuan pemerintah pusat (Djpk-Kemenkeu, 2011:22). Berdasarkan kajian teori diatas maka hipotesis penelitian ini adalah:

$\mathrm{H}_{1}$ : Pajak daerah berpengaruh terhadap tingkat kemandirian keuangan daerah.

$\mathrm{H}_{2}$ : Retribusi daerah berpengaruh terhadap tingkat kemandirian keuangan daerah

$\mathrm{H}_{3}$ : DBH berpengaruh terhadap tingkat kemandirian keuangan daerah

$\mathrm{H}_{4}$ : Belanja Modal berpengaruh terhadap tingkat kemandirian keuangan daerah

$\mathrm{H}_{5}$ : Pertumbuhan Ekonomi berpengaruh terhadap tingkat kemandirian Keuangan Daerah

$\mathrm{H}_{6}$ : Pajak daerah, retribusi daerah, DBH, belanja modal, dan pertumbuhan 
ekonomi secara simultan berpengaruh terhadap tingkat kemandirian keuangan daerah.

\section{METODE PENELITIAN}

Indonesia memiliki 33 Provinsi dan

514 kabupaten/kota. Populasi dalam penelitian ini adalah seluruh kabupaten/kota di Provinsi Jawa Timur tahun 2014-2017 yang terdiri dari 38 kabupaten/kota (29 kabupaten da 9 kota). Teknik pengambilan sampel dalam penelitian ini yaitu dengan menggunakan sensus dimana seluruh popilasi digunakan dan diselidiki.

Jenis penelitian ini adalah penelitian kuantutatif. Data yang digunakan dalam penelitian ini adalah data sekunder yang berasar dari Laporan Realisasi Anggaran kabupaten/kota di Jawa Timur tahun 20142017 dan Laporan PDRB Jawa Timur tahun 2014-2017.

Metode pengumpulan data dalam penelitian ini yanitu menggunakan metode dokumentasi. Metode ini digunakan untuk memperoleh data mengenai data pajak daerah, retribusi daerah, $\mathrm{DBH}$, belanja modal, PAD serta PDRB Jawa Timur tahun 2014-2017. Teknik analisis yang digunakan dalam penelitian ini adalah teknik analisis deskriptif. Alat analisis yang digunakan adalah uji linear berganda. Uji hipotesis yang digunakan dalam penelitian ini adalah uji $t$ dan uji F. Semua diuji dengan menggunakan software SPSS. Adapun untuk pengukuran variabel dapat dirumuskan sebagai berikut:

a. Pajak Daerah = Pajak Daerah/Total Pendapatan Daerah X 100\% (Nggilu, dkk., 2016)

b. Retribusi Daerah = Retribusi Daerah/ Total Pendapatan Daerah X 100\% (Nggilu, dkk., 2016)

c. $\mathrm{DBH}=\mathrm{DBH} /$ Total Pendapatan Daerah X 100\% (Hutasoit, 2017)

d. Belanja Modal = Belanja Modal/Belanja Daerah X 100\% (Darwis, 2015)

e. Pertumbuhan Ekonomi $=\left(\mathrm{PDRB}_{\mathrm{t}}-\right.$ PDRB $_{\mathrm{t}-1} \quad$ )/PDRB $\mathrm{PD}_{\mathrm{t}-1} \quad \mathrm{X} \quad 100 \%$ (Sudrajat, 2017)

f. Kemandirian Keuangan Daerah = PAD/Total Pendapatan Daerah X 100\% (Hutasoit, 2017)

\section{HASIL DAN PEMBAHASAN}

Penelitian ini menggunakan dua variabel, yaitu variabel independen dan variabel dependen. Adapun variabel independen dalam penelitian ini adalah pajak daerah, retribusi daerah, DBH, belanja modal, dan pertumbuhan ekonomi. Sedangkan variabel dependen dalam penelitian ini adalah kemandirian keuangan daerah. Berikut adalah hasil dari analisis uji deskriptif dapat dilihat pada tabel di bawah ini:

Tabel 1. Deskriptive Statities

\begin{tabular}{llllll}
\hline & $\mathrm{N}$ & Minimum & Maximum & Mean & $\begin{array}{l}\text { Std. } \\
\text { Devation }\end{array}$ \\
\hline Pajak & 152 & .008 & .590 & .08683 & .091998
\end{tabular}




\begin{tabular}{lrllll}
\hline Daerah & & & & & \\
Retribusi & 152 & .005 & .081 & .01546 & .011059 \\
Daerah & & & & & \\
DBH & 152 & .025 & .568 & .05981 & .058671 \\
$\begin{array}{l}\text { Belanja } \\
\text { Modal }\end{array}$ & 152 & .102 & .370 & .20454 & .046574 \\
$\begin{array}{l}\text { Pertumbuhan } \\
\text { Ekonomi }\end{array}$ & 152 & -.027 & .220 & .05496 & .020979 \\
$\begin{array}{l}\text { Kemandirian } \\
\text { Daerah }\end{array}$ & 152 & .008 & .643 & .14173 & .101670 \\
$\begin{array}{l}\text { Valid N } \\
\text { (listwise) }\end{array}$ & 152 & & & & \\
\hline
\end{tabular}

Sumber: Data Diolah (2019)

Berdasarkan tabel di atas dapat dilihat bahwa $\mathrm{N}$ sampel sebanyak 152 . Pajak daerah kabupaten/kota di Jawa Timur mempunyai nilai minimum sebesar 0,008, dan nilai maximum sebesar 0,590, dengan rata-rata 0,08683 dan nilai standar devation sebesar 0,091998. Retribusi daerah kabupaten/kota di Jawa Timur mempunyai nilai minimum sebesar 0,005 , dan nilai maximum sebesar 0,081, dengan rata-rata 0,01546 dan nilai standar devation sebesar 0,011059. DBH kabupaten/kota di Jawa Timur mempunyai nilai minimum sebesar 0,025, dan nilai maximum sebesar 0,568, dengan rata-rata 0,05981 dan nilai standar devation sebesar 0,011059. Belanja modal kabupaten/kota di Jawa Timur mempunayai nilai minimum 0,102 , dan nilai maximum sebesar 0,370, dengan rata-rata 0,20454 dan nilai standar devation sebesar 0,045674. Pertumbuhan ekonomi kabupaten/kota di ujian adalah sebagai berikut:
Jawa Timur mempunyai nilai minimum sebesar -0,027, dan nilai maximum sebesar 0,220 , dengan rata-rata 0,05496 dan nilai standar devation sebesar 0,020979. Kemandirian daerah kabupaten/kota di Jawa Timur mempunyai nilai minimum 0,008 , dan nilai maximum sebesar 0,643 , dengan rata-rata 0,14173 dan nilai standar devation sebesar 0,101670 .

Sebelum melakukan uji hipotesis, maka perlu dilakukan uji asumsi klasik terlebih dahulu untuk memperoleh hasil regresi yang baik. Uji asumsi klasik terdiri dari uji normalitas, uji multikolinearitas, uji autokorelasi, dan uji heterokedastisitas. Uji normalitas bertujuan untuk mendeteksi apakah dalam regresi ini variabel independen dan variabel dependen terdistribusi secara normal atau tidak. Adapun hasil peng 


\begin{tabular}{ccc}
\hline Normal Parameters a,b & Mean & $0 \mathrm{E}-7$ \\
& Std. Devation & .05586772 \\
Most Extreme Differences & Absolute & .099 \\
& Positive & .099 \\
& Negative & -.055 \\
Kolmogorov-Smirnov Z & & 1.224 \\
Asymp. Sig. (2-tailed) & & .100 \\
\hline
\end{tabular}

Sumber: Data Diolah (2019)

Hasil tabel diatas terlihat bahwa

gejala tersebut dapat dilihat dari hasil nilai nilai asyimp. Sig. (2-tailed) sebesar 0,100, nilainya lebih besar dari 0,05 . Hal ini berarti data residual terdistribusi normal.

Uji multikolinearitas digunakan untuk menguji apakah dalam sebuah regresi terdapat adanya korelasi antar variabel independennya. Apabila terjadi korelasi maka dikatakan terdapat gejala multikolinearitas. Pengujian ada tidaknya

Tabel 3. Hasil Uji Multikolinearitas

\begin{tabular}{llc}
\hline Model & \multicolumn{2}{c}{ Collinearity Statities } \\
\hline & Tolerance & VIF \\
Pajak Daerah & .580 & 1.725 \\
Retribusi Daerah & .587 & 1.702 \\
DBH & .815 & 1.228 \\
Belanja Modal & .939 & 1.065 \\
Pertumbuhan Ekonomi & .807 & 1.240 \\
\hline
\end{tabular}

a. Dependent Variabel Kemandirian Daerah

Sumber: Data Diolah (2019)

Hasil tabel di atas terlihat nilai VIF dari masing-masing variable lebih besar dari 10 (VIF > 10), sedangkan nilai tolerance lebih besar dari 0,1 (tolerance > 0,1). Dari hasil tersebut dapat dikatakan persamaan regresi tidak terdapat gejala multikolinearitas.

Uji autokorelasi digunakan untuk menguji apakah dalam regresi linear

terdapat korelasi antara kesalahan pengganggu pada periode sekarang dengan periode sebelumnya. Gejala tersebut dapat dideteksi dengan menggunakan uji DW (Durbin Watson). Apabila DW lebih dari +2 dan kurang dari -2, maka dikatakan telah terjadi gejala autokorelasi. Berikut adalah hasil dari uji autokorelasi dapat dilihat pada tabel di bawah ini:

Tabel 4. Hasil Uji Autokorelasi

\begin{tabular}{llllll}
\hline Model & R Square & $\begin{array}{l}\text { Adjusted } \\
\text { Square }\end{array}$ & $\begin{array}{l}\text { R } \\
\text { Estimate } \\
\text { Estimer of the }\end{array}$ & $\begin{array}{l}\text { Durbin- } \\
\text { Watson }\end{array}$ \\
\hline 1 & $.835^{\mathrm{a}}$ & .698 & .688 & .056816 & .372 \\
\hline
\end{tabular}


Sumber: Data Diolah (2019)

Hasil uji autokorelasi yang dapat dilihat pada tabel di atas menunjukkan model regresi terdapat nilai DW sebesar 0,372 . Nilai DW berada heterokedastisitas atau tidak. Untuk diantara +2 dan -2 , maka dapat dikatakan mengetahuinya dapat dilihat pada gambar dibawah ini: bahwa tidak terdapat gejala autokorelasi.

Uji heterokedastisitas digunakan untuk melihat apak dalam

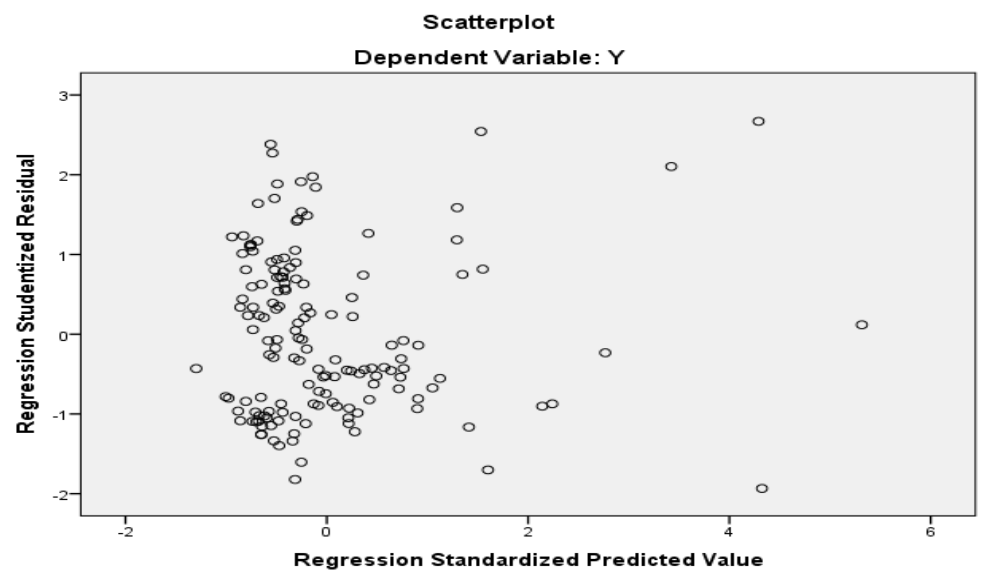

Gambar 1. Hasil Uji Heterokedastisitas

Gambar di atas dapat di lihat titiktitik menyebar secara acak dan baik di atas maupun di bawah angka 0 pada sumbu Y. Hal tersebut menunjukkan bahwa model regresi dalam penelitian ini tidak terdapat gejala heterokedastisitas.

Hubungan antara dua variabel atau lebih dapat dilihat dengan menggunakan analisis regresi berganda. Analisis regresi berganda juga dapat digunakan untuk menunjukkan arah hubungan antar variabel bebas dan variabel terikat. Berikut adalah hasil dari uji analisis regresi berganda yang dapat dilihat pada tabel di bawah ini:

Tabel 5. Hasil Uji Analisis Regresi Berganda

\begin{tabular}{llccc}
\hline \multirow{2}{*}{ Model } & \multicolumn{2}{c}{ Understandardized Coefficients } & $\begin{array}{c}\text { Standardized } \\
\text { Coefficients }\end{array}$ \\
\cline { 3 - 5 } & & $\mathrm{B}$ & Std. Error & Beta \\
& (Constant) & .082 & .023 & .692 \\
& Pajak Daerah & .765 & .066 & .220 \\
Retribusi Daerah & 2.026 & .546 & .026 \\
DBH & .046 & .087 & -.099 \\
Belanja Modal & -.216 & .102 & .014 \\
\hline
\end{tabular}

Sumber: Data Diolah (2019) 
Dari tabel diatas dapat dituliskan

persamaan regresi sebagai berikut:

\section{Kemandirian Daerah $=$ 0,082 + 0,765 Pajak Daerah + 2,026 Retribusi Daerah + 0,046 DBH - 0,216 Belanja Modal + 0,070 Pertumbuhan Ekonomi}

Hal ini menunjukkan konstanta sebesar 0,082 berarti jika pajak daerah,retribusi daerah. $\mathrm{DBH}$, belanja modal, dan pertumbuhan ekonomi dianggap tidak ada atau sama dengan 0 maka akan diperoleh nilai kemandirian sebesar 0,082. Pajak daerah bernilai 0,765 artinya setiap peningkatan pajak sebesar satu satuan maka nilai kemandirian keuangan daerah akan naik sebesar 0,765. Retribusi daerah bernilai 2,026 artinya setiap peningkatan retribusi sebesra satu satuan maka nilai kemandirian akan naik sebesar 2,026. DBH bernilai 0,046 artinya setiap peningkatan DBH sebesar satu satuan maka kemandirian akan naik sebesar 0,046. Belanja modal bernilai 0,216 bearah negative artinya setiap peningkatan belanja modal sebesar satu satuan maka nilai kemandirian akan turun sebesar 0,216. Pertumbuhan ekonomi bernilai 0,070 artinya setiap peningkatan ertumbuhan ekonomi sebesar satu satuan maka nilai kemandirian akan naik sebesar 0,070 .

Uji hipotesis terdiri dari tiga uji yaitu uji koefisien determinasi, uji t, dan uji F. Uji koefisien determinasi bertujuan untuk mlihat seberapa erat dan terikatnya anatara variabel bebas dan variabel terikat. Untuk mengetahunya maka dapat dilihat pada tabel di bawah ini:

Tabel 6. Hasil Uji Koefisien Determinasi

\begin{tabular}{lllcl}
\hline Model & $\mathrm{R}$ & R Square & $\begin{array}{c}\text { Adjusted R } \\
\text { Square }\end{array}$ & $\begin{array}{l}\text { Std. Error of } \\
\text { the Estimate }\end{array}$ \\
\hline 1 & $.835^{\mathrm{a}}$ & .698 & .688 & .056816 \\
\hline
\end{tabular}

Sumber: Data Diolah (2019)

Tabel di atas dapat dilihat nilai adjusted $R$ square sebesar 0,688 . Hal ini berarti $68,8 \%$ variabel kemandirian keuangan daerah dapat dijelaskan oleh variabel yang ada dalam penelitian ini dan sisanya sebesar $31,2 \%$ dijelaskan oleh variabel diluar penelitian ini.

Uji t digunakan untuk mengetahui pengaruh variabel bebas terhadap variabel terikat. Berikut adalah hasil dari uji t yang dapat dilihat pada tabel dibawah ini:

Tabel 7. Hasil Uji t

\begin{tabular}{llll}
\hline Model & & $\mathrm{T}$ & Sig. \\
\hline 1 & (Constant) & 3.478 & .001 \\
\hline
\end{tabular}




\begin{tabular}{lll}
\hline Pajak Daerah & 11.582 & .000 \\
Retribusi Daerah & 3.714 & .000 \\
DBH & .525 & .600 \\
Belanja Modal & -2.106 & .037 \\
Pertumbuhan Ekonomi & .283 & .777 \\
\hline
\end{tabular}

Sumber: Data Diolah (2019)

Hasil tabel di atas menujukkan hasil dari uji t. Hasilnya adalah hipotesis pertama diterima, hal ini karena pajak daerah memilki tingkat signifikan 0,000 lebih kecil dari 0,05 artinya pajak daerah berpengaruh terhadap kemandirian keuangan daerah. Hasil tersebut sejakan dengan penelitian yang dilakukan oleh Novalistia (2016) dan penelitian Sunyoto dan Sunarto (2016) yang keduanya menyimpulkan bahwa pajak daerah berpengaruh positif signifikan terhadap kemandirian keuangan daerah. Semakin tinggi rakyat berpastripisai dalam pembayaran pajak akan menggambarkan kesejahteraan masyarakat sehingga suatu kemandirian dapat tercapai.

Hipotesis kedua dalam penelitian ini diterima, hal ini karena retribusi daerah memiliki tingkat signifikan 0,000 lebih kecil dari 0,05 artinya retribusi daerah berpengaruh terhadap kemandirian keuangan daerah. Hasil ini sejalan dengan penelitian yang dilakukan oleh Nggilu (2016) yang menyimpulkan nahwa retribusi daerah berpengaruh positif signifikan terhadap tingkat kemandirian keuangan daerah. Daerah yang dapat menghasilkan retribusi yang tinggi dan maksimal akan dapat mempermudah daerah tersebut mencapai kemandirian.

Hipotesis ketiga dalam penelitian ini ditolak, hal ini karena DBH memiliki tingkat signifikan sebesar 0,600 lebih besar dari 0,05, artinya DBH tidak berpengaruh terhadap kemandirian daerah. Hasil ini sejalan dengan penelitian yang dilakukan pleh Marizka (2013), yang menyimpulkan bahwa DBH tidak berpengaruh terhadap kemandirian keuangan daerah. Pembagian DBH yang tidak tepat waktu akan menghambat proses pembangunan suatu daerah. Jika proses pembangunan terhambat maka kemandirian akan sulit untuk tercapai.

Hipotesis keempat dalam penelitian ini diterima, hal ini karena belanja modal memilki tingkat signifikan sebesar 0,037 lebih kecil dari 0,05, koefisien belanja modal bearah nehatif, artinya belanja modal berpengaruh negative terhadap kemandirian keuangan daerah. Hasil ini sejalan dengan penelitian yang dilakukan Darwis (2015) yang hasilnya menyimpulkan nahwa belanja modal berpengaruh negative signifikan terhadap kemandirian keuangan daerah. Hal ini dapat terjadi mungkin disebabkan oleh belanja modal yang dilakukan belum merata sehingga terjadi ketimpangan kemandirian diantar daerah.

Hipotesis kelima dalam penelitian ini ditolak, hal ini karena pertumbuhan ekonomi memiliki tingkat signifikan sebesar 0,777 lebih besar dari 0,05, artinya pertumbuhan ekonomi tidak berpengaruh terhadap kemandirian keuangan daerah. Hasil ini sejalan dengan penelitian yang dilakukan oleh Gaghana, dkk. (2018) yang hasilnya menyimpulkan bahwa pertumbuhan ekonomi tidak berpengaruh terhadap kemandirian keuangan daerah. Hal ini disebabkan Karena pertumbuhan ekonomi di Jawa Timur belum merata. 
Uji f digunakan untuk mengetahui pengaruh variabel independen secara bersama-sama terhadap variabel dependennya. Untuk mengetahuinya maka dapat dilihat pada tabel di bawah ini:

Tabel 8. Hasil Uji F

\begin{tabular}{|c|c|c|c|c|c|c|}
\hline \multicolumn{7}{|c|}{$\begin{array}{c}\text { Tabel 8. Hasil Uji F } \\
\text { ANOVA }^{\text {b }}\end{array}$} \\
\hline Model & & $\begin{array}{l}\text { Unstandardized } \\
\text { Coefficients }\end{array}$ & Df & $\begin{array}{l}\text { Mean } \\
\text { Square }\end{array}$ & $\mathrm{F}$ & Sig. \\
\hline \multirow[t]{3}{*}{1} & Regression & 1.090 & 5 & .218 & 67.504 & $.000^{\mathrm{b}}$ \\
\hline & Residual & .471 & 146 & .003 & & \\
\hline & Total & 1.561 & 151 & & & \\
\hline
\end{tabular}

Sumber: Data Diolah (2019)

Hasil dari uji $\mathrm{F}$ terdapat hasil nilai F hitung sebesar 67,504 lebih besar dari $\mathrm{F}$ tabelnya sebesar 2,43 (67,04 > 2,43). Dari hasil tersebut maka dapat dikatakan hipotesis keenam diterima, yaitu pajak daerah, retribusi daerah, $\mathrm{DBH}$, belanja modal, dan pertumbuhan ekonomi secara simultan berpengaruh terhadap kemandirian keuangan daerah.

\section{KESIMPULAN DAN SARAN}

Berdasarkan pada hasil pengujian yang sudah dilakukan maka dapat di simpulkan: Pajak daerah mempunyai pengaruh terhadap kemandirian keuangan daerah di kabupaten dan kota Provinsi Jawa Timur tahun 2014-2017. Retribusi daerah mempunyai pengaruh terhadap kemandirian keuangan daearh di kabupaten dan kota Provinsi Jawa Timur tahun 2014-2017..DBH tidak mempunyai pengaruh terhadap kemandirian keuangan daerah di kabupaten dan kota Provinsi Jawa Timur. Belanja modal mempunyai pengaruh negative terhadap kemandirian keuangan daerah di Provinsi Jawa Timur. Pertumbuhan ekonomi tidak mempunyai pengaruh terhadap kemandirian keuangan daerah di kabupaten dan kota Provinsi Jawa Timur. Pajak daerah, retribusi daerah, DBH, belanja modal, dan pertumbuhan ekonomi secara bersama- sama mempunyai pengaruh terhadap kemandirian keuangan daerah di kabupaten dan kota Provinsi Jawa Timur.Berdasarkan pada kesimpulan di atas maka penulis memberikan saran sebagai berikut:

1. Bagi Pemerintah

Pemerintah sebaiknya lebih fokus pada pengoptimalan PAD untuk membiayai kegiatan pemerintahannya agar kemandirian dapat tercapai.

2. Bagi peneliti selanjutnya

a. Peneliti selanjutnya diharapakan dapat melakukan penelitian kembali dengan menambah variabel lain yang lebih bervariasi dan dianggap dapat mempengaruhi kemandirian keuangan daerah.

b. Peneliti selanjutnya disarankan dapat memperluas populasi dan sampel penelitian dan dapat menambah tahun atau periode penelitian.

\section{DAFTAR PUSTAKA}

BPS. (2019). Retrieved Januari 27, 2019, from www.bps.go.id

Darwis, E. T. (2015). Pengaruh Belanja Modal Dan Belanja Pegawai 
Terhadap Tingkat Kemandirian Keuangan Daerah Pada Kabupaten/Kota Provinsi Sumatera Barat (Studi Empiris Pada Kabupaten/Kota Sumatera Barat). Karya Ilmiah : Universitas Negeri Padang .

DJPK. (2011). Deskripsi Data Analisis APBD 2011. Retrieved Januari 27, 2019, from www.djpk.kemenkeu.go.id

DJPK. (2019). Direktorat Jendral Perimbangan Keuangan. Retrieved Januari 27, 2019, from www.djpk.kemenkeu.go.id

Erawati, N. T., \& Suzan, L. (2015). Pengaruh Pendapatan Asli Daerah Terhadap Tingkat Kemandirian Keuangan Daerah Kota Bandung (Studi Kasus Pada DPKAD Kota Bnadung Periode 2009-2013). EProceeding Of Management: Vol 2

Gaghana, R. L., Kindangen, P., \& Rotinsulu, D. C. (2018). Pengaruh Pertumbuhan Ekonomi Dan Pendapatan Asli Daerah Terhadap Tingkat Kemandirian Keuangan Daerah (Studi Kasus Pada Koata Manado, Kota Bitung, Kota Toomohon, dan Kota Kotamobagu). Jurnal Pembanguna Ekonomi dan Keuangan Daerah. Vol 19 No. 7.

Ghozali, I. (2013). Aplikasi Analisis Multivariete Dengan Program IBM SPSS 23. Semarang: Universitas Diponegoro.

Halim, A., \& Kusufi, M. S. (2014). Akuntansi Sektor Publik (Akuntansi Keuangan Daerah). Jakarta: Salemba Empat.

Hambali, A. A. (2018). Kemandirian Bojonegoro Relatif Masih Rendah. Retrieved Januari 11, 2019, from
Detak Pos Opinion: www.detakpos.com

Hutasoit, R. K. (2017). Pengaruh Pendapatan Asli Daerah, Dana Bagi Hasil, Dana Alokasi Umum, Dana Alokasi Khusus, Terhadap Tingkat Kemandirian Keuangan Daerah Pada Pemerintah Kabupaten/Kota Di Jawa Barat. Skripsi: Universitas Sumatera Utara .

Mahsun, M. (2013). Pengukuran Kinerja Sektor Publik. Yogyakarta : BPFEYogyakarta.

Marizka, R. (2013). Pengaruh Pendapatan Asli Daerah, Dana Bagi Hasil, Dana Alokasi Umum, Dan Dana Alokasi Khusus Terhadap Tingkat Kemandirian Keuangan Daerah Pada Kabupaten Dan Kota Di Sumatera Barat . Artikel Ilmiah: Universitas Negeri Padang .

Nggilu, F., Harijanto, S., \& Victorina, T. (2016). Pengaruh Pajak Daerah Dan Retribusi Daerah Terhadap Kemandirian Keuangan Daerah Pada Pemerintahan Kabupaten/Kota Di Provinsi Gorontalo. Jurnal Berkala Ilmiah Efisiensi. Volume 16 No. 14 .

Novalistia, R. L. (2016). Pengaruh Pajak Daerah, Retribusi Daerah, Lainlain Pendapatan Yang Sah, Dana Bagi Hasil Pajak Terhadap Kemandirian Keuangan Daerah Pada Pemerintah Kabupaten/Kota Di Provinsi Jawa Tengah. Journal Of Accounting Volume 2 .

Nurdiwaty, D., Badrus, Z., \& Efda, K. (2017). Analisis Pengaruh Pertumbuhan Ekonomi, Pendapatan Asli Daerah, Dana Perimbangan, Dan Lain-lain Pendapatan Yang Sah Terhadap Belanja Modal Di Jawa Timur. 
Jurnal Aplikasi Bisnis, Vol. 17 No. 1 .

Nwanne. (2015). Effects Of Tax Policy On The Expenditure of Local Govverment Councils In Imo State. European Journal of Accounting Auditing and Finance Research, Vol. 3, No. 12 .

Putro, P. U. (2013). Pengaruh PDRB dan Ukuran Terhadap Pengendalian Intern Pemerintah Daerah dengan PAD Sebagai Variabel Intervening. Skripsi Publikasi: Universitas Negeri Semarang .

Sanga, K. P., Suwardi, B. H., \& Nur, H. (2018). Pengaruh Penerimaan Daerah Terhadap Kemandirian Keuangan Daerah Dengan Belanja Modal Sebagai Variabel Intervening. Konferensi Regional Akuntansi V. Sekolah Tinggi Ilmu Ekonomi (STESIA) Surabaya , 3.

Siregar, B. (2015). Akuntansi Sektor Publik (Akuntansi Keuangan
Pemerintah Berbasis Akrual). Yogyakarta: UPP STIM YKPN.

Sudrajat, M. A., \& Purniawati, I. (2017). Analisis Pengaruh PAD, DBH, DAU, DAK, dan Pertumbuhan Ekonomi Terhadap Belanja Modal Kabupaten Ngawi Tahn 20132015. Jurnal Akuntansi Prodi Akuntansi- FEB UNIPMA Vol. 1, No. 1 .

Sugiyono. (2017). Metode Penelitian Kuantitatif, Kualitatif, dan $R \& D$. Bandung: Alfabeta.

Sunarto, \& Sunyoto. (2016). Pengaruh Pajak Daerah Dan Retribusi Daerah Terhadap Kemandirian Daerah Yang Berdampak Pada Pertumbuhan Ekonomi Daerah (Studi Kasus Pada Kabupaten/Kota di Provinsi Jawa Tengah). Dharma Ekonomi No. 43/Th. XXIII/ April 2016. ISSN: 0853-5205. 